\title{
EFEKTIVITAS PELAKSANAAN PASAL 66 PERDA NOMOR 1 TAHUN 2016 TENTANG KETERTIBAN UMUM DI KOTA SINGKAWANG
}

\author{
Tamrin Muchsin ${ }^{1}$, Sri Sudono Saliro ${ }^{2}$, Sardjana Orba Manullang 3 , Nahot Tua Parlindungan \\ Sihaloho ${ }^{4}$ \\ ${ }^{1}$ Institut Agama Islam Sultan Muhammad Syafiuddin Sambas \\ ${ }^{2}$ Institut Agama Islam Sultan Muhammad Syafiuddin Sambas \\ ${ }^{3}$ Universitas Krisnadwipayana \\ ${ }^{4}$ FISIP Universitas Tanjungpura
}

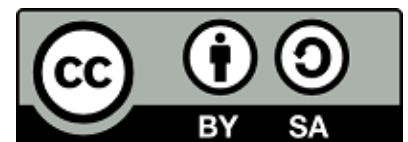

DOI: http://dx.doi.org/10.33603/hermeneutika.v3i2

Diterima: Juli 2020; Direvisi: 31 Agustus 2020; Dipublikasikan: Agustus 2020

\begin{abstract}
Abstrak: Layang-layang adalah salah satu permainan tradisional yang dimainkan di berbagai penjuru dunia. Permainan ini dimainkan oleh berbagai kalangan usia mulai dari anak-anak hingga dewasa. Pada konteks bermain layangan, di wilayah hukum Kota Singkawang telah mengatur secara eksplisit didalam Pasal 66 Perda No. 1 Tahun 2016 Tentang Ketertiban Umum, Pasal tersebut mengatur "setiap orang dilarang bermain layangan dengan menggunakan kawat dan benang gelasan yang dapat membahayakan keselamatan orang lain", dan "setiap orang dilarang bermain layangan di jalanan, jalur hijau, taman fasilitas umum dan fasilitas sosial yang dapat membahayakan keselamatan orang lain". Tulisan ini mengangkat rumusan masalah yang akan dikaji yaitu, bagaimana efektivitas pelaksanaan Pasal 66 (larangan bermain layangan) pada Perda No. 1 Tahun 2016 Tentang Ketertiban Umum di Kota Singkawang. Metode penelitian artikel ini menggunakan metode penelitian hukum empiris dengan menjabarkan data analisis deskriptif, untuk memperoleh data dilakukan observasi dan wawancara, selain itu juga melalui dokumen, data tertulis dari Satpol PP Singkawang. Temuan hasil penelitian mengungkapkan bahwa pelaksanaan Pasal 66 Perda No. 1 Tahun 2016 Tentang Ketertiban Umum di Kota Singkawang terlaksana secara efektif, dari sudut pandang faktor hukum itu sendiri, faktor penegakan hukum dan faktor sarana.
\end{abstract}

Kata kunci: Efektivitas, Peraturan Daerah, Layangan, Kota Singkawang

\footnotetext{
${ }^{1}$ Tamrin Muchsin

Email : tamrinmuchsin69@gmail.com

${ }^{2}$ Sri Sudono Saliro

Email : srisudonosalirofh@gmail.com

${ }^{3}$ Sardjana Orba Manullang

Email : somanullang@unkris.ac.id

${ }^{4}$ Nahot Tua Parlindungan Sihaloho

Email : nahotsihaloho@fisip.untan.ac.id
} 


\section{PENDAHULUAN}

Layang-layang sebagai sebuah permainan tradisional yang dikenal diseluruh penjuru dunia. Permainan ini dimainkan oleh berbagai kalangan usia mulai dari anak-anak hingga dewasa. Sejarah panjang layang-layang membuat permainan ini memiliki jenis dan bentuk yang sangat beragam. Mengingat sejarah panjang kehadiran layang-layang dan begitu luas penyebarannya, asal-usul layang-layang ini secara tepat masih menjadi teka-teki. ${ }^{1}$

Bukti yang tercatat di dalam dokumen sejarah menyebutkan bahwa layang-layang bermula dari Cina sekitar 2500 tahun yang lalu dan kemudian menyebar ke negara-negara lain. ${ }^{2}$ Oleh karena itu, layang-layang semakin banyak dikenal dan digemari dibanyak Negara. Di Indonesia sendiri, layang-layang biasanya diadakan event ataupun perlombaan pada acara tertentu. Di Kota Singkawang, telah banyak dijumpai baik dari kalangan muda maupun tua yang bermain layang-layang, hal ini merupakan hiburan tersendiri bagi pencinta layangan.

Namun disisi lain, layang-layang menjadi masalah yang umum dan telah banyak terjadi diberbagai kota, termasuk Kota Singkawang. Oleh karena itu layanglayang juga bisa menjadi faktor penyebab suatu daerah dikatakan jauh dari rasa tertib dan aman. Pengaturan hukum dibuat untuk menjaga ketertiban umum yaitu melalui produk hukum Peraturan Daerah (Perda). Perda ini diarahkan guna pencapaian kondisi yang kondusif bagi seluruh aspek kehidupan bermasyarakat sehingga diharapkan mempunyai posisi yang strategis dan penting untuk menumbuhkembangkan budaya disiplin masyarakat agar terwujud tata kehidupan

1 Betha Almanfaluthi dan Juniar, "Konsep Motion Graphics Pengenalan Layang-Layang Sebagai Budaya Bangsa," Jurnal Desain Volume 7, no. 2, Januari-April 2020 (2020): hlm. 100, doi:http://dx.doi.org/10.30998/jd.v7i2.5361.

${ }^{2}$ Ibid., hlm. 101.
Kota Singkawang yang lebih aman dan nyaman. ${ }^{3}$

Pemerintah daerah memiliki kewenangan untuk mengatur dan mengurus sendiri urusan pemerintahan menurut asas otonomi dan tugas pembantuan dan diberikan otonomi yang seluas-luasnya, guna untuk mempercepat terwujudnya kesejahteraan masyarakat melalui pelayanan, pemberdayaan, peran serta masyarakat dan penyelesaian masalah yang berhubungan dengan ketertiban umum. Hal ini termuat di dalam UndangUndang Dasar Negara Republik Indonesia Tahun 1945 yang menyebutkan bahwa pemerintahan daerah Provinsi, daerah Kabupaten dan Kota mengatur dan mengurus sendiri urusan pemerintahan menurut asas otonomi dan tugas pembantuan. ${ }^{4}$

Atas dasar hukum itu, Pemerintah daerah perlu membentuk Peraturan Daerah tentang Ketertiban Umum. Pada konteks bermain layangan, di wilayah hukum Kota Singkawang telah diatur secara eksplisit didalam Pasal 66 Peraturan Daerah Kota Singkawang Nomor 1 Tahun 2016 Tentang Ketertiban Umum (Perda Singkawang No. 1 Tahun 2016 tentang ketertiban umum). Pasal tersebut mengatur "setiap orang dilarang bermain layangan dengan menggunakan kawat dan benang gelasan yang dapat membahayakan keselamatan orang lain", dan "setiap orang dilarang bermain layangan di jalanan, jalur hijau, taman fasilitas umum dan fasilitas sosial yang dapat membahayakan keselamatan orang lain".

Perda Singkawang No. 1 Tahun 2016 tentang ketertiban umum sudah jelas dan tegas menyatakan bahwa setiap orang tidak diperbolehkan bermain layang-

3 "Peraturan Daerah Kota Singkawang Nomor 1 Tahun 2016 Tentang Ketertiban Umum” (2016), Lihat Penjelasan pada Perda No. 1 Tahun 2016 Tentang Ketertiban Umum.

${ }^{4}$ MPR Sekretariat Jenderal, "Undang-Undang Dasar Negara Republik Indonesia Tahun 1945" (2006), Lihat Pasal 18 ayat (2). 
layang yang membahayakan keselamatan orang lain.

Setiap orang yang hendak bermain layang-layang seharusnya mengetahui dan memperhatikan peraturan perundangundangan yang berlaku, termasuk Perda Singkawang No. 1 Tahun 2016 tentang ketertiban umum. Sebab apabila tidak memperhatikan, maka akan menjadi suatu fenomena sosial dan dapat menjadi suatu masalah yang kompleks yang cenderung menimbulkan bahaya bagi masyarakat. Seperti halnya yang dikemukakan oleh Koptu Rusdi (Babinsa 1202-05/skw) bahwa beberapa hari belakangan pemain kelayangan meresahkan petani. Pemain kelayangan menggunakan gelasan maupun kawat yang bisa merugikan orang lain termasuk petani dan PLN. ${ }^{5}$

Berangkat dari persoalan sebagaimana dikemukakan diatas, maka dalam tulisan ini akan mengkaji mengenai keefektivan Perda yang mengatur tentang larangan bermain layangan. Tulisan ini mengangkat rumusan masalah yang akan dikaji yaitu, bagaimana efektivitas pelaksanaan Pasal 66 (larangan bermain layangan) pada Perda No. 1 Tahun 2016 Tentang Ketertiban Umum di Kota Singkawang ?.

\section{METODE PENELITIAN}

Metode penelitian artikel ini menggunakan metode penelitian hukum empiris dengan menjabarkan data analisis deskriptif yang berupa kata-kata tertulis atau lisan dari orang-orang dan prilaku yang diamati. Menurut Soerjono Soekanto bahwa hukum empiris adalah suatu metode penelitian hukum lapangan atau faktual keadaan yang terjadi pada lingkungan

\footnotetext{
5 Rizki Kurnia, "Bikin Resah, Kodim Singkawang Dorong Pembentukan Satgas PenertibanPemain Layangan," Tribun Pontianak (website: tribunpontianak.co.id), 22 Juni 2020, diakses tanggal 13 Juli 2020.
}

Satpol PP Singkawang Kota Singkawang. ${ }^{6}$ Pada konteks ini mengkaji ketentuan hukum Perda Singkawang No. 1 tahun 2016 tentang Ketertiban Umum, khususnya Pasal 66 terhadap keadaan sebenarnya terjadi di Kota Singkawang. Selanjutnya, setelah data yang dibutuhkan terkumpul kemudian menuju kepada identifikasi masalah yang pada akhirnya menuju pada penyelesaian masalah. ${ }^{7}$

Sumber data penelitian adalah subjek dimana data dapat diperoleh. ${ }^{8}$ Sumber data pada penelitian ini adalah tempat dimana ditemukan, diperoleh dan dikumpulkan suatu informasi atau data mengenai penegakan Perda No. 1 Tahun 2016 tentang ketertiban Umum, khususnya Pasal 66 . Data primer yaitu data yang diperoleh secara langsung dari Anggota Satpol PP Singkawang Kota Singkawang sebagai sumber pertama dengan melalui penelitian lapangan yang berupa keterangan-keterangan dari pihak yang terkait yaitu wawancara. Selain itu, dilakukan teknik observasi adalah pengamatan dan pencatatan secara sistematis terhadap gejala yang tampak pada objek penelitian. ${ }^{9}$ Data Sekunder, yaitu data yang diperoleh dari studi kepustakaan yang berupa buku-buku, perundang-undangan, arsip asas-asas hukum dan dokumen yang berkaitan dengan masalah yang diteliti.

\section{HASIL PENELITIAN \\ 1. Satpol PP Sebagai Aparat Penegak Hukum Daerah.}

6 Soerjono Soekanto, Pengantar Penelitian Hukum (Jakarta: UI Press, 2006), hlm. 9.

7 Bambang Waluyo, Penelitian Hukum Dalam Praktek (Jakarta: Sinar Grafika, 2002), hlm.15.

8 Arikunto Suharsimi, Prosedur Penelitian Suatu Pendekatan Praktik (Jakarta: Rineka Cipta, 2010), hlm. 172.

9 Norman K. Denzin, Yvonna S. Lincoln (editor), dan Dariyatno (penerjemah), Handbook of Qualitative Research (edisi ketiga) (Yogyakarta: Pustaka Pelajar, 2009), hlm. 505. 
Istilah Pamong Praja berasal dari dua kata yaitu "pamong" dan "praja". Pamong mempunyai arti pengurus, pengasuh atau pendidik. Sedangkan Praja memiliki arti kota, negeri atau kerajaan. Pamong artinya pengasuh yang berasal dari kata Among yang juga mempunyai arti sendiri yaitu mengasuh, sedangkan Praja adalah pegawai negeri, Pangreh. Praja atau Pegawai Pemerintahan.Menurut Kamus Besar Bahasa Indonesia Pamong Praja adalah Pegawai Negeri yang mengurus pemerintahan Negara. ${ }^{10}$ Definisi lain mengenai Polisi Pamong Praja adalah sebagai salah satu Badan Pemerintah yang bertugas memelihara keamanan dan ketertiban umum atau pegawai Negara yang bertugas menjaga keamanan. ${ }^{11}$ Sehingga secara harfiah Pamong Praja dapat di artikan sebagai pengurus kota.Satpol PP, merupakan salah satu perangkat yang dimiliki oleh Pemerintah Daerah dalam memelihara ketentraman dan ketertiban umum serta menegakkan Peraturan Daerah. Organisasi dan tata kerja Satpol PP ditetapkan dengan Perda.Satpol PP dapat berkedudukan di Daerah Provinsi dan Kabupaten/Kota. ${ }^{12}$

Salah satu perangkat pemerintahan daerah yang bertujuan untuk membantu kepala daerah dalam rangka menegakkan peraturan daerah dan penyelenggaraan ketertiban umum dan ketentraman masyarakat adalah Satpol PP. Pada dasarnya pembentukan Satpol PP ini lahir dari beberapa ketentuan yang termuat di dalam Pasal 256 UU No. 23 Tahun 2014 tentang Pemerintah Daerah, dan secara lebih khusus keberadaan Satpol PP ini diakomodir di dalam Peraturan Pemerintah

${ }^{10}$ Alwi Hasan, Kamus Besar Bahasa Indonesia (Jakarta: Balai Pustaka, 2005), hlm. 817.

11 Suhaimi, "Reinterpretasi dan Reformulasi Makna Jihad dan Qital (Studi Historis Islam dalam Tafsir Tematik)," Jurnal El-Furqania Volume 3, no. 1, Februari (2017): hlm. 3.

12 Sapto Wahyono, "Perspektif Hukum Atas Peran Satuan Polisi Pamong Praja dalam Penegakan Peraturan Daerah dan Peraturan Kepala Daerah," Jurnal Yustitia Volume 20, no. 2, Desember (2019): hlm. 174-175.
Nomor 16 Tahun 2018 tentang Satuan Polisi Pamong Praja, selanjutnya disingkat PP No. 16 Tahun 2018 tentang Satpol PP. ${ }^{13}$

Satpol PP sebagai perangkat daerah, mempunyai peran yang sangat strategis dalam memperkuat otonomi daerah dan pelayanan publik di daerah. Untuk menjamin terlaksananya tugas Satpol PP dalam penegakan Perda dan Perkada, penyelenggaraan ketertiban umum dan ketenteraman serta pelindungan masyarakat perlu dilakukan peningkatan, baik dari sisi kelembagaan maupun sumber daya manusia. Selain itu, keberadaan Satpol PP dalam penyelenggaraan pemerintahan daerah diharapkan dapat membantu adanya kepastian hukum dan memperlancar proses pembangunan di daerah. $^{14}$

\section{Dalam Peraturan Pemerintah} Nomor 16 Tahun 2018 yang dimaksud dengan Satpol PP adalah perangkat daerah yang dibentuk untuk menegakkan Peraturan Daerah dan Peraturan Kepala Daerah, menyelenggarakan ketertiban umum dan ketenteraman serta menyelenggarakan pelindungan masyarakat. ${ }^{15}$ Sedangkan Polisi Pamong Praja yang selanjutnya disebut Pol PP adalah anggota Satpol PP sebagai aparat Pemerintah Daerah yang diduduki oleh pegawai negeri sipil dan diberi tugas, tanggung jawab, dan wewenang sesuai dengan peraturan perundang-undangan dalam penegakan Peraturan Daerah dan Peraturan Kepala Daerah, penyelenggaraan ketertiban umum dan ketenteraman serta pelindungan masyarakat. ${ }^{16}$

13 Ni Ketut Hevy Yushantini, "Tinjauan Kewenangan Antara Satpol PP dan Polri dalam Menciptakan Ketertiban dan Keamanan," Jurnal Kertha Semaya Volume 8, no. 6 (2020): hlm. 971.

${ }^{14}$ Victor Imanuel W Nalle, "Studi Sosio-Legal Terhadap Ketertiban dan Ketentraman di Kabupaten Sidoarjo," Jurnal Hukum \& Pembangunan Volume 47, no. 3 (2016): hlm. 385.

15 "Peraturan Pemerintah Republik Indonesia Nomor 16 Tahun 2018 Tentang Satuan Polisi Pamong Praja" (2018), Lihat Pasal 1 angka 1.

${ }^{16}$ Ibid., Lihat Pasal 1 angka 2. 
Hukum berfungsi sebagai perlindungan kepentingan manusia. Agar kepentingan manusia terlindungi, hukum harus dilaksanakan. ${ }^{17}$ Satpol PP sebagai perangkat daerah, mempunyai peran yang sangat strategis dalam memperkuat otonomi daerah dan pelayanan publik di daerah. Untuk menjamin terlaksananya tugas Satpol PP dalam penegakan Perda dan Perkada, penyelenggaraan ketertiban umum dan ketenteraman serta pelindungan masyarakat perlu dilakukan peningkatan, baik dari sisi kelembagaan maupun sumber daya manusia. ${ }^{18}$

Selain itu, keberadaan Satpol PP dalam penyelenggaraan pemerintahan daerah diharapkan dapat membantu adanya kepastian hukum dan memperlancar proses pembangunan di daerah. Untuk itu dalam Undang-Undang Nomor 23 Tahun 2014 ditegaskan bahwa Satuan polisi pamong praja dibentuk untuk menegakkan Perda dan Perkada, menyelenggarakan ketertiban umum dan ketenteraman, serta menyelenggarakan pelindungan masyarakat. Sedangkan dalam Pasal 5 Peraturan Pemerintah Nomor 16 Tahun 2018 ditegaskan bahwa tugas Satpol PP adalah : a) menegakkan Perda dan Perkada, b) menyelenggarakan ketertiban umum dan ketenteraman; dan c) menyelenggarakan pelindungan masyarakat. ${ }^{19}$

Pembentukan Satpol PP pada mulanya untuk mengatasi celah keorganisasian antara kepala wilayah dan kepala Polri setempat. Berdasarkan peraturan perundang-undangan yang berlaku, kepala wilayah dibebani tanggung

17 Sudikno Mertokusumo, Ilmu Hukum, Cet IV (Bandung: Citra Aditya Bakti, 2006), hlm. 15.

18 Wahyono, "Perspektif Hukum Atas Peran Satuan Polisi Pamong Praja dalam Penegakan Peraturan Daerah dan Peraturan Kepala Daerah," hlm. 176.

19 Peraturan Pemerintah Republik Indonesia Nomor 16 Tahun 2018 Tentang Satuan Polisi Pamong Praja, Lihat Pasal 5. jawab atas pembinaan ketentraman dan ketertiban wilayah yang juga menjadi tugas utama polri. Tetapi dalam pembebanannya kurang dilengkapi dengan wewenang untuk menggerakan Polri sebagai alat pelaksana. Jadi struktur pemerintahan daerah yang ada tidak menjamin berlangsungnya pelaksanaan tugas kepala wilayah secara otomatis. Kebutuhan kepala wilayah akan alat pelaksana, yang dapay digerakan secara langsung tidak dapat dihindari. Kondisi demikian mendesak pemerintah pusat untuk membentuk satuan tersebut yang langsung berada di bawah kepala wilayah. ${ }^{20}$

Dalam melaksanakan tugas sebagaimana dimaksud dalam Pasal 5, Satpol PP mempunyai fungsi sebagai berikut: a) penyusunan program penegakan Perda dan Perkada, penyelenggaraan ketertiban umum dan ketenteraman serta penyelenggaraan pelindungan masyarakat; b) pelaksanaan kebijakan penegakan Perda dan Perkada, penyelenggaraan ketertiban umum dan ketentraman masyarakat serta penyelenggaraan perlindungan masyarakat; c) pelaksanaan koordinasi penegakan Perda dan Perkada, penyelenggaraan ketertiban umum dan ketentraman serta penyelenggaraan perlindungan masyarakat dengan instansi terkait; d) pengawasan terhadap masyarakat, aparatur atau badan hukum atas pelaksanaan Perda dan Perkada ; dan, e) pelaksanaan fungsi lain berdasarkan tugas yang diberikan oleh Kepala Daerah sesuai dengan peraturan perundangundangan. ${ }^{21}$

Kewenangan Satpol PP diatur dalam Pasal 7 PP No. 16 Tahun 2018 tentang Satpol PP yang menyebutkan

20 Djaenal Hoesen Koesoemahatmadja, Fungsi dan Struktur Pamong Praja (Bandung: Alumni, 2002), hlm. 193.

21 Peraturan Pemerintah Republik Indonesia Nomor 16 Tahun 2018 Tentang Satuan Polisi Pamong Praja, Lihat Pasal 6. 
dalam melaksanakan tugas dan fungsinya, Satpol PP berwenang: a) Melakukan tindakan penertiban non-yustisial terhadap warga masyarakat, aparatur, atau badan hukum yang melakukan pelanggaran atas Perda dan/atau Perkada; b) Menindak warga masyarakat, aparatur, atau badan hukum yang mengganggu ketertiban umum dan ketenteraman masyarakat; c) Melakukan tindakan penyelidikan terhadap warga masyarakat, aparatur, atau badan hukum yang diduga melakukan pelanggaran atas Perda dan/atau Perkada; dan d) Melakukan tindakan administratif terhadap warga masyarakat, aparatur, atau badan hukum yang melakukan pelanggaran atas Perda dan/atau Perkada. ${ }^{22}$

Berdasarkan ketentuan-ketentuan tersebut di atas maka dapat dikatakan kewenangan Satpol PP antara lain untuk menegakkan Perda dan Perkada, menyelenggarakan ketertiban umum dan ketenteraman serta menyelenggarakan perlindungan masyarakat. ${ }^{23}$ Kewenangan yang sah jika ditinjau dari mana kewenangan itu diperoleh menurut F.A,M. Stroink dan J.G. Steenbeek, maka dapat dilihat pada dua sumber kewenangan yakni kewenangan atributif dan kewenangan delegatif. Kedua cara organ pemerintah dalam memperoleh kewenangan itu, dijadikan dasar atau teori untuk menganalisis kewenangan aparatur negara di dalam menjalankan kewenangannya. Kewenangan atributif lazimnya digariskan atau berasal dari adanya pembagian kekuasaan Negara oleh UUD NRI 1945 biasanya berkenaan dengan penyerahan wewenang baru, sedangkan kewenangan delegatif merupakan kewenangan yang bersumber dari pelimpahan suatu organ pemerintahan kepada organ lain dengan dasar peraturan perundang-undangan dan menyangkut pelimpahan wewenang yang telah ada, oleh organ yang telah

${ }^{22}$ Ibid., Lihat Pasal 7.

23 Gunawan, "Penyelenggaraan Ketentraman dan Ketertiban Umum Satpol PP dan Penyidik Pegawai Negeri Sipil di Provinsi Aceh," Jurnal Bina Praja Volume 8, no. 2, Juni (2012): hlm. 117. memperoleh wewenang secara atributif kepada organ lain, jadi secara logis selalu didahului oleh atribusi. ${ }^{24}$

$$
\text { Adapun }
$$

penyelenggaraan

ketertiban umum dan ketentraman masyarakat yang dilakukan oleh Satpol PP meliputi kegiatan: a) deteksi dan cegah dini; b) pembinaan dan penyuluhan; c) patroli; d) pengamanan; e) pengawalan; f) penertiban; dan g) penanganan unjuk rasa dan kerusuhan massa. ${ }^{25}$

\section{Efektivitas Pelaksanaan Pasal 66 Perda Ketertiban Umum di Kota Singkawang}

Terciptanya masyarakat yang tertib diharapkan mampu untuk melindungi masyarakat dan kepentingan mereka. Di dalam mewujudkan tujuan hukum, terdapat tugas yang harus dipenuhi seperti kewajiban dan hak perorangan dalam masyarakat dibagi, kewenangannya juga harus dibagi, dan pengaturan tentang penyelesaian problematika hukum, serta memelihara kepastian hukum. Pasal 255 Undang-Undang Nomor 23 Tahun 2014 tentang Pemerintahan Daerah mengatur kewenangan Satpol PP, yang diciptakan dalam rangka ditegakkannya peraturan daerah dan peraturan kepala daerah, serta berwenang melakukan tindakan penertiban, tindakan penyelidikan dan tindakan administratif terhadap warga masyarakat yang melanggar aturan-aturan.

Hal ini senada dengan ketentuan yang termuat dalam Perda Singkawang No. 1 Tahun 2016 tentang Ketertiban Umum, pada konteks penelitian ini yaitu Pasal 66 yang mengatakan bahwa setiap orang dilarang bermain layangan dengan menggunakan kawat dan benang gelasan yang dapat membahayakan keselamatan

24 Ari Kurniawan Putra, "Studi Kewenangan Pemerintah Daerah Penyidik Pegawai Negeri Sipil (PPNS) Satuan Polisi Pamong Praja di Kabupaten Pelalawan Tahun 2014-2016.," JOM FISIP Volume 4, no. 2 (2017): hlm. 6-7.

25 Peraturan Pemerintah Republik Indonesia Nomor 16 Tahun 2018 Tentang Satuan Polisi Pamong Praja, Lihat Pasal 11. 
orang lain, dan setiap orang dilarang bermain layangan di jalanan, jalur hijau, taman fasilitas umum dan fasilitas sosial yang dapat membahayakan keselamatan orang lain. Pelaksanaan hukum dapat terjadi karena pelanggaran hukum, yakni dengan menegakan hukum dengan alat-alat perlengkapan Negara, salah satunya dalam penegakan Perda adalah Satpol PP.

Pada konteks untuk melihat sejauh mana efektivitas dari penegakan hukum itu sendiri, peneliti akan menganalisis menggunakan teori efektivitas hukum menurut Soerjono Soekanto. Teori ini adalah teori untuk menganalisis efektif atau tidaknya suatu hukum ditentukan oleh 5 (lima) faktor, yaitu: 1) faktor hukum itu sendiri, 2) faktor penegakan hukum, 3) faktor sarana, 4) faktor masyarakat, 5) faktor kebudayaan. ${ }^{26}$ Kelima faktor tersebut saling berkaitan dengan eratnya, oleh karena merupakan esensi dari penegakan hukum, juga merupakan tolak ukur daripada efektifitas penegakan hukum. Dengan demikian, maka kelima faktor tersebut akan dibahas pada artikel ini.

\section{1) Faktor hukum itu sendiri}

Konteks artikel ini, maka yang diartikan dengan hukum itu sendiri dalam arti materiel adalah peraturan tertulis yang berlaku umum dan dibuat pemerintah daerah yang sah yaitu Perda Singkawang No. 1 Tahun 2016 Tentang Ketertiban Umum. Mengenai berlakunya Perda ini tentu terdapat beberapa kejelasan tujuan yang hendak dicapai agar Perda mempunyai dampak positif. Maksudnya adalah perda tersebut mencapai tujuannya sehingga efektif.

Tujuan yang dimaksud adalah untuk mewujudkan Kota Singkawang yang aman dan nyaman serta menciptakan suatu kondisi yang dinamis dimana pemerintah

26 Soerjono Soekanto, Faktor-Faktor Yang Mempengaruhi Penegakan Hukum Cetakan Ke XII (Jakarta: Rajawali Pers, 2013), hlm. 8. dan masyarakat dapat melaksanakan kegiatannya dengan tertib, teratur dan tentram perlu adanya pengaturan hukum berkenaan dengan ketertiban umum. Pengaturan Hukum yang baik dalam ketertiban Umum adalah Perda. Perda ketertiban umum diarahkan guna pencapaian kondisi yang kondusif bagi seluruh aspek kehidupan bermasyarakat sehingga diharapkan mempunyai posisi yang strategis dan penting untuk menumbuhkembangkan budaya disiplin masyarakat agar terwujud tata kehidupan Kota Singkawang yang lebih aman dan nyaman.

Berdasarkan hasil wawancara dengan bapak Hartadi27, bapak Drs. Jarvid $^{28}$, M.Si, bapak Edi Prawoko, SH 29 dan Ibu Evi Susilawati ${ }^{30}$, yang mana semuanya merupakan anggota Satpol PP Kota Singkawang mengatakan bahwa dengan adanya Perda Singkawang No. 1 Tahun 2016 tentang Ketertiban Umum, khususnya Pasal 66 mengenai pengaturan larangan bermain layang-layang, memberikan asas kepastian hukum dalam suatu perundang-undangan. Asas legalitas/kepastian hukum ini, menjadi landasan dasar anggota Satpol PP Kota Singkawang dalam menindak atau melakukan pengawasan terhadap masyarakat yang bermain layangan dengan menggunakan kawat dan benang gelasan yang dapat membahayakan keselamatan orang lain.

27 Wawancara dengan Bapak Hartadi, SH, sebagai Anggota Satpol PP Singkawang, tanggal 19 Agustus, 2020.

${ }^{28}$ Wawancara dengan Bapak Drs. Jarvid, M.Si, sebagai Kabid Penegakan Perundang-Undangan Daerah Satpol PP Singkawang, tanggal 19 Agustus, 2020.

${ }^{29}$ Wawancara dengan Bapak Edi Prawoko, SH, sebagai Anggota Satpol PP Singkawang, tanggal 19 Agustus, 2020.

30 Wawancara dengan Ibu Evi Susilawati, sebagai Anggota Satpol PP Singkawang, tanggal 19 Agustus, 2020. 
Dari hasil paparan diatas,
menyatakan bahwa kehadiran Perda
Singkawang tentang ketertiban umum,
merupakan asas kepastian hukum dalam
melakukan penegakan hukum.

\section{2) Faktor penegakan hukum}

Hasil wawancara dengan bapak Hartadi $^{31}$, bapak Drs. Jarvid ${ }^{32}$, M.Si, bapak Edi Prawoko, SH ${ }^{33}$ dan Ibu Evi Susilawati ${ }^{34}$, pada tanggal 19 Agustus 2020 di Kantor Satpol PP Kota Singkawang, bahwa kasus pelanggaran Pasal 66 pada tahun 2019 sebanyak 1 kasus dan tahun 2020 tidak ada kasus pelanggaran terhadap Pasal 66. Yang mana penegakan hukum yang dilakukan oleh Satpol PP terhadap pelanggaran Pasal 66 yaitu melalui himbauan kepada masyarakat yang bermain layangan, selain itu, melakukan pembinaan dan pengawasan terhadap aktifitas masyarakat yang suka bermain layangan, serta mengamankan/merazia beberapa tali gelasan dan kelayangan. Selanjutnya, bagi pelaku yang bermain kelayangan yang mengakibatkan korban mengalami luka atau kecelakaan akibat dari tali kelayangan, maka akan diproses sesuai dengan Perda Singkawang No. 1 Tahun 2016 tentang Ketertiban Umum.

dari paparan hasil wawancara menyatakan bahwa penegakan hukum terhadap Pasal 66 yang dilakukan oleh Satpol PP Kota Singkawang, terkesan pasif, artinya menunggu adanya jatuh korban terlebih dahulu, kemudian Perda tersebut ditegakan. Tentunya peneliti memahami bahwa hal tersebut Satpol PP lakukan karena Satpol PP pasti memiliki

31 Wawancara dengan Bapak Hartadi, SH, sebagai Anggota Satpol PP Singkawang, tanggal 19 Agustus.

32 Wawancara dengan Bapak Drs. Jarvid, M.Si, sebagai Kabid Penegakan Perundang-Undangan Daerah Satpol PP Singkawang, tanggal 19 Agustus.

${ }^{33}$ Wawancara dengan Bapak Edi Prawoko, SH, sebagai Anggota Satpol PP Singkawang, tanggal 19 Agustus.

34 Wawancara dengan Ibu Evi Susilawati, sebagai Anggota Satpol PP Singkawang, tanggal 19 Agustus. beberapa pertimbangan sosiologis yang tentunya untuk kepentingan bersama. Hal ini senada dengan apa yang dikemukakan oleh Notohamidjojo yang menyatakan terdapat 4 (empat) norma penting dalam penegakan hukum, yaitu kemanusiaan, keadilan, kepatutan dan kejujuran. ${ }^{35}$ Dan menurut Dwi Haryadi yang mengatakan bahwa hukum itu untuk manusia, maka hukum harus berbasis nurani dan bukan materi. ${ }^{36}$

\section{3) Faktor Sarana}

Tanpa adanya sarana atau fasilitas tertentu, maka tidak mungkin penegakan hukum akan berlangsung dengan lancar. Hasil wawancara dengan anggota Satpol PP Kota Singkawang, mengatakan bahwa Dalam rangka menjalankan tugas pokok dan fungsi khususnya dalam hal pengaturan, penjagaan, pengawalan dan patroli serta operasional dilakukan serangkaian kegiatan yang menunjang baik untuk Satuan Polisi Pamong Praja Kota Singkawang sendiri maupun tugas-tugas Kedinasan Walikota, Wakil Walikota, Sekretaris Daerah serta para Asisten di lingkungan Sekretariat Daerah Kota Singkawang. Beberapa Dinas/Instansi pernah melakukan koordinasi baik dalam hal penegakan Peraturan Daerah maupun Peraturan pelaksanaannya khususnya mengenai penegakan disiplin, penanganan unjuk rasa, penertiban dan dukungan penertiban yang dilakukan oleh beberapa Satuan Kerja Perangkat Daerah di Lingkungan Kota Singkawang. Pelayanan Pengaduan juga telah disiapkan oleh Satuan Polisi Pamong Praja Kota Singkawang. Pelayanan Pengaduan ini dibuka selama 24 jam, yang dilaksanakan di dua tempat, yaitu pertama : laporan pengaduan dilaksanakan di Sekretariat Pelayanan Pengaduan Satuan Polisi Pamong Praja Kota Singkawang pada jam

35 Notohamidjojo, Soal-Soal Pokok Filsafat Hukum (Salatiga: Griya Media, 2011), hlm. 41.

36 Dwi Haryadi, PEMIKIRAN HUKUM SPIRITUAL PLURALISTIK: Membangun Penegakan Hukum Bernurani (Yogyakarta: Thafa Media, 2016), hlm. 331. 
kerja pegawai, sedangkan kedua : laporan pengaduan dilaksanakan pada Pos Penjagaan Induk Satuan Polisi Pamong Praja Kota Singkawang di Kantor Walikota Singkawang di luar jam kerja Sekretariat PPNS Kota Singkawang. Di Sekretariat tersebut, Satuan Polisi Pamong Praja Kota Singkawang berkedudukan sebagai koordinator.

hal ini menunjukan pada aspek sarana dalam bentuk pelayanan. Dalam hal ini pelayanan pengaduan/laporan dilaksanakan 24 jam. Artinya Satpol PP memfasilitasi masyarakat dalam hal ketertiban dan ketentraman masyarakat.

\section{4) Faktor Masyarakat}

Faktor ini menekankan pada lingkungan dimana hukum tersebut berlaku atau diterapkan. Berdasarkan hasil wawancara dengan anggota Satpol PP Kota Singkawang, bahwa masyarakat masih kurang patuh terhadap hukum. Hal ini dibuktikan dengan masih banyaknya masyarakat yang bermain layangan menggunakan tali gelasan dan kawat.

\section{5) Faktor Kebudayaan}

Pada faktor kebudayaan ini, tidak relevan dengan pembahasan, maka dari itu

\section{DAFTAR PUSTAKA}

Almanfaluthi, Betha, dan Juniar. "Konsep Motion Graphics Pengenalan LayangLayang Sebagai Budaya Bangsa." Jurnal Desain Volume 7, no. 2, JanuariApril 2020 (2020): 99-109. doi:http://dx.doi.org/10.30998/jd.v7i2.5 361 .

Arikunto Suharsimi. Prosedur Penelitian Suatu Pendekatan Praktik. Jakarta: Rineka Cipta, 2010.

Djaenal Hoesen Koesoemahatmadja. Fungsi dan Struktur Pamong Praja. Bandung: Alumni, 2002.

Gunawan. "Penyelenggaraan Ketentraman dan Ketertiban Umum Satpol PP dan Penyidik Pegawai Negeri Sipil di Provinsi Aceh." Jurnal Bina Praja atau hari libur lainnya. Selain membuka pelayanan pengaduan, Satuan Polisi Pamong Praja Kota Singkawang juga akan membentuk

faktor kebudayaan tidak termasuk dalam tolak ukur efektivitas pelaksanaan Pasal 66 mengenai larangan bermain layangan.

Berdasarkan paparan analisis diatas, artikel ini menyimpulkan bahwa efektivitas penegakan hukum terhadap larangan bermain layangan menurut Pasal 66 Perda Singkawang No. 1 Tahun 2016 tentang Ketertiban Umum, telah dilaksanakan secara efektif, yang mana kehadiran Perda tersebut merupakan landasan dasar bagi Satpol PP untuk melakukan penegakan hukum.

\section{KESIMPULAN}

Efektivitas pelaksanaan larangan bermain layangan menurut Pasal 66 Perda Singkawang No. 1 Tahun 2016 Tentang Ketertiban Umum telah dilaksanakan secara efektif, yaitu dilihat dari sudut pandang faktor hukum itu sendiri, faktor penegakan hukum dan faktor sarana.

Volume 8, no. 2, Juni (2012): pp 117126.

Haryadi, Dwi. PEMIKIRAN HUKUM SPIRITUAL PLURALISTIK: Membangun Penegakan Hukum Bernurani. Yogyakarta: Thafa Media, 2016.

Hasan, Alwi. Kamus Besar Bahasa Indonesia. Jakarta: Balai Pustaka, 2005.

Kurnia, Rizki. "Bikin Resah, Kodim Singkawang Dorong Pembentukan Satgas PenertibanPemain Layangan.” Tribun Pontianak (website: tribunpontianak.co.id), 22 Juni 2020.

Mertokusumo, Sudikno. Ilmu Hukum, Cet IV. Bandung: Citra Aditya Bakti, 2006. 
MPR Sekretariat Jenderal. UndangUndang Dasar Negara Republik Indonesia Tahun 1945 (2006).

Nalle, Victor Imanuel W. "Studi SosioLegal Terhadap Ketertiban dan Ketentraman di Kabupaten Sidoarjo." Jurnal Hukum \& Pembangunan Volume 47, no. 3 (2016).

Norman K. Denzin, Yvonna S. Lincoln (editor), dan Dariyatno (penerjemah). Handbook of Qualitative Research (edisi ketiga). Yogyakarta: Pustaka Pelajar, 2009.

Notohamidjojo. Soal-Soal Pokok Filsafat Hukum. Salatiga: Griya Media, 2011.

Peraturan Daerah Kota Singkawang Nomor 1 Tahun 2016 Tentang Ketertiban Umum (2016).

Peraturan Pemerintah Republik Indonesia Nomor 16 Tahun 2018 Tentang Satuan Polisi Pamong Praja (2018).

Putra, Ari Kurniawan. "Studi Kewenangan Pemerintah Daerah Penyidik Pegawai Negeri Sipil (PPNS) Satuan Polisi Pamong Praja di Kabupaten Pelalawan Tahun 2014-2016." JOM FISIP Volume 4, no. 2 (2017).

Soekanto, Soerjono. Faktor-Faktor Yang Mempengaruhi Penegakan Hukum Cetakan Ke XII. Jakarta: Rajawali Pers, 2013.

—. Pengantar Penelitian Hukum. Jakarta: UI Press, 2006.
Suhaimi. "Reinterpretasi dan Reformulasi Makna Jihad dan Qital (Studi Historis Islam dalam Tafsir Tematik)." Jurnal El-Furqania Volume 3, no. 1, Februari (2017).

Wahyono, Sapto. "Perspektif Hukum Atas Peran Satuan Polisi Pamong Praja dalam Penegakan Peraturan Daerah dan Peraturan Kepala Daerah." Jurnal Yustitia Volume 20, no. 2, Desember (2019): pp 172-183.

Waluyo, Bambang. Penelitian Hukum Dalam Praktek. Jakarta: Sinar Grafika, 2002.

Wawancara dengan Bapak Drs. Jarvid, M.Si, sebagai Kabid Penegakan Perundang-Undangan Daerah Satpol PP Singkawang, tanggal 19 Agustus, 2020.

Wawancara dengan Bapak Edi Prawoko, SH, sebagai Anggota Satpol PP Singkawang, tanggal 19 Agustus, 2020.

Wawancara dengan Bapak Hartadi, SH, sebagai Anggota Satpol PP Singkawang, tanggal 19 Agustus, 2020.

Wawancara dengan Ibu Evi Susilawati, sebagai Anggota Satpol PP Singkawang, tanggal 19 Agustus, 2020.

Yushantini, Ni Ketut Hevy. "Tinjauan Kewenangan Antara Satpol PP dan Polri dalam Menciptakan Ketertiban dan Keamanan." Jurnal Kertha Semaya Volume 8, no. 6 (2020): pp 967-981. 